\title{
Identification and cloning of the porcine ROSA26 promoter and its role in transgenesis
}

\author{
Ping Li ${ }^{1}$, Christopher Burlak ${ }^{1}$, Jose Estrada' ${ }^{1}$ Peter J. Cowan ${ }^{2}$ and A. Joseph Tector ${ }^{1 *}$ \\ *Correspondence: atector@iupui.edu \\ ${ }^{1}$ Indiana University Health Transplant Institute, Department of Surgery, Indiana University School of Medicine, Indianapolis, Indiana, \\ USA. \\ 'Immunology Research Centre, St. Vincent's Hospital Melbourne, Melbourne, Victoria, Australia.
}

\begin{abstract}
Several promoters from different origins have been used to drive transgene expression in pigs with variable results. In this study, we identified porcine ROSA26 promoter located on chromosome 13. Porcine ROSA26 promoter was cloned and its activity was examined using enhanced green fluorescence protein (EGFP) as a reporter. EGFP expression was detected in adult liver derived cells (LDC) by flow cytometry and confocal microscopy after transient transfection. Stable LDC expressing EGFP were established and used as nuclear donors for somatic cell nuclear transfer (SCNT). Two hundred thirty-three reconstructed embryos were transferred to two recipients. One pregnancy was established. A total of four fetuses were collected at day 30 of gestation, one normal and three resorbed. All fetuses had EGFP gene integration. Confocal microscope analysis showed that EGFP was expressed in fetal liver, heart, and isolated fetal fibroblasts. These results indicated that ROSA26 promoter is a ubiquitous promoter and can be utilized in pig transgenesis.
\end{abstract}

Keywords: ROSA26 locus, promoter, transgenesis, enhanced green fluorescence protein

\section{Introduction}

The current goal of xenotransplantation is to genetically modify pigs to overcome the acute humoral response and thrombocytopenia that limits long term transplantation of pig organs [1]. The success of xenotransplantation relies on the application of molecular biology tools to insert a transgene or silence a xenoantigen gene to prevent platelet consumption or rejection of the xenografts. Recent progress in pig cloning has significantly improved transgenic efficiency, through the selection of transgenic cells prior to somatic cell nuclear transfer (SCNT). To date, pigs transgenic for genes regulating human complement, apoptosis, coagulation, inflammation and platelet activation have been generated [2]. Transgenic pigs expressing graft-protective proteins such as human CD46, CD55, CD59 and CD39 reduced the incidence of hyperacute rejection [3,4]. However, transgenesis has some limitations, such as unpredictability of expression and inheritance of the transgene. This unpredictability is due to transgene random integration (positional effect) as well as promoter silencing. It is important to select a promoter that will drive a significant level of expression of the transgene in all or the desired pig tissue. A variety of promoters originating from human, mouse, chicken, and virus have been used in pig transgenesis with variable outcome, including the promoters for the genes of human $\beta 2 \mathrm{~m}, \mathrm{EF}-1 \mathrm{a}, \mathrm{CD} 46$, mouse $\mathrm{H}-2 \mathrm{~K}^{\mathrm{b}}$, chicken b-actin, cytomegalovirus and respiratory syncytial virus [5].

The ROSA26 locus has become established as the preferred docking site for transgene expression. Mouse, human and rat
ROSA26 locus have been characterized. The mouse ROSA26 promoter was identified by random retroviral gene trapping in embryonic stem cells [6]. Targeting of the ROSA26 site with the reporter b-gal resulted in ubiquitous expression in various tissues and in hematopoietic cells during embryonic development [7]. The human and rat ROSA26 loci have been subsequently identified and showed to accommodate ubiquitous expression of the reporter genes $[\mathbf{8 , 9}]$. Besides transgenes, short hairpin RNA (shRNA) expression within the mouse ROSA26 locus created a reproducible and inducible knockdown of gene expression $[10,11]$. The ROSA26 locus is an ideal docking site for transgenes as it supports stable expression and overcomes concerns of gene disruption or alteration through insertional mutagenesis. Yet, the pig ROSA26 promoter and ROSA26 locus have not been characterized.

In this study, we cloned and sequenced the porcine ROSA26 promoter located on chromosome 13. Porcine ROSA26 promoter strength was compared to the mouse $\mathrm{H}-2 \mathrm{~K}^{\mathrm{b}}$ and $\mathrm{CMV}$ promoters in vitro, and in vivo activity was examined in 30-day old fetuses.

\section{Materials and methods}

\section{Cloning porcine ROSA26 promoter}

The porcine ROSA26 promoter sequence was obtained by searching pig genome database (NCBI) using mouse ROSA26 promoter sequence and human ROSA26 promoter sequence as references. Primers ROSA26-F(5'GGCGCGCCCAGGATGCAAGAGTCTTAGGC3') and ROSA26-R (5'ACGCGTGTGTTTT (ACACACGGCGGGAGG3') were designed to amplifying a $3.9 \mathrm{~kb}$

(c) 2014 Tector et al; licensee Herbert Publications Ltd. This is an Open Access article distributed under the terms of Creative Commons Attribution License (http://creativecommons.org/licenses/by/3.0). This permits unrestricted use, distribution, and reproduction in any medium, provided the original work is properly cited. 
Li et al. Transplantation Technology 2014,

DNA fragment harboring potential porcine ROSA26 promoter by PCR using domestic pig genomic DNA as a template. Ascl and Mlul sites were added to the 5 ' of forward and reverse primers, respectively (underlined). Pwo SuperYield DNA Polymerase (Roche, Indianapolis, IN) was used and PCR conditions were as follows: $94^{\circ} \mathrm{C}, 2$ minutes; $94^{\circ} \mathrm{C}, 15$ seconds, $55^{\circ} \mathrm{C}, 30$ seconds; $72^{\circ} \mathrm{C} 4$ minutes for 15 cycles; $94^{\circ} \mathrm{C}, 15$ seconds, $55^{\circ} \mathrm{C}, 30$ seconds; $72^{\circ} \mathrm{C} 4$ minutes and 5 seconds added to each cycle for 25 cycles; and a final extension step of $72^{\circ} \mathrm{C}$ for 8 minutes. The $P C R$ product was subsequently cloned into $P C R-X L-T O P O$ vector (Invitrogen, Carlsbad, CA) to generate pCR-XL-ROSA26. Porcine ROSA26 promoter was sequenced using primers 7124 (5'ATTACCTCTGTCCTCCAAGCAGCC3'), 7807 (5' CACCATTCACTTCGCATC $\left.3^{\prime}\right)$, 8571 (5'TTTCTGTCGCACCCTTACC $3^{\prime}$ ), 9334 (5'GGAAAAGCCTGGAATACG3'), 9740 (5' GTCCCAAATGAGCGAAAC 3'), 10241 (5'GTCAGTTTGCTCCTTCTCG 3'), 10415 (5' AATGAGTCCAGGCAACACC3'), 10632 (5' GCATCCTTACGGTCAGATAAC3').

\section{Construction of transgenic vector}

CMV promoter and multiple cloning site (MCS) of pEGFP-N1 (Clontech, Palo Alto, CA) was replaced by a linker Asel-NrulAscl-Sall-Mlul-Pvul-BamHI. A $3.9 \mathrm{~kb}$ fragment containing potential porcine ROSA26 promoter was excised from pCR$\mathrm{XL}-\mathrm{ROSA} 26$ with Ascl and Mlul digestion and inserted to the promoterless pEGFP-N1 between Ascl and Mlu I sites, resulting in plasmid pROSA26-EGFP. The control vector was constructed by cloning of EGFP CDNA to the downstream of murine $\mathrm{MHC}$ class I $\mathrm{H}-2 \mathrm{~K}^{\mathrm{b}}$ promoter at EcoRI site, resulting in plasmid $\mathrm{pH}-2 \mathrm{~K}^{\mathrm{b}}-\mathrm{EGFP}$.

\section{Transient transfection}

Liver derived cells (LDCs) were isolated as described previously [12]. LDCs were cultured in combination media (a-MEM:EGMMV 3:1) (Invitrogen/Lonza) supplemented with 10\%FBS (Hyclone), 10\% horse serum (Invitrogen, Cat \# 16050-122), 12 $\mathrm{mM}$ Hepes and 1\% Pen/Strep (Invitrogen, Carlsbad, CA) on collagen I coated plates and maintained at $37^{\circ} \mathrm{C}$ with $5 \% \mathrm{CO}_{2}$ and $10 \% \mathrm{O}_{2}$. To compare promoter strength among ROSA26, $\mathrm{H}-2 \mathrm{~K}^{\mathrm{b}}$, and CMV, LDC were transfected with pROSA26-EGFP, $\mathrm{pH}-2 \mathrm{~K}^{\mathrm{b}}$-EGFP and pEGFP-N1 by using Neon ${ }^{\mathrm{TM}}$ Transfection System (Invitrogen, Carlsbad, CA) as per the manufacturer instructions. $3 \times 10^{5}$ cells were mixed with $1.5 \mu \mathrm{g}$ of each DNA, respectively, and electroporated at $1300 \mathrm{~V}, 30 \mathrm{~ms}, 1$ pulse. Then cells were cultured at $37^{\circ} \mathrm{C}$ with $5 \% \mathrm{CO}_{2}$ and $10 \% \mathrm{O}_{2}$. After 48 hours, cells were harvested and EGFP expression was examined by flow cytometry. Untransfected LDC were used as a control. Data was shown as a representative histogram and relative mean fluorescent intensity with standard deviation. Relative mean fluorescent intensity was determined by setting the highest value in each experiment to 1 to allow accurate comparison between experiments. Flow cytometric analysis of EGFP reporter expression is a sensitive way for the detection of promoter activity [13].

\section{Establishment of EGFP stable cell line}

LDC at $80-90 \%$ confluence were harvested with trypsin and washed with calcium and magnesium free DPBS (Invitrogen, Carlsbad, CA). pROSA26-EGFP was linearized by Asc I digestion. Transfection was performed by using Neon ${ }^{\mathrm{TM}}$ Transfection System (Invitrogen). Briefly, $10^{6}$ cells were suspended in 120 $\mu \mathrm{l}$ of $\mathrm{R}$ buffer and $2 \mu \mathrm{g}$ of linearized DNA was added. Cells were electroporated at $1300 \mathrm{~V}, 30 \mathrm{~ms}, 1$ pulse, and plated onto collagen I coated plates (BD) in the culture media without antibiotics. After 48 hours, the culture media was replaced with selection media containing $100 \mu \mathrm{g} / \mathrm{ml}$ of G418 (Invitrogen). After 10 days of G418 selection the EGFP positive cells were isolated by flow sorting. The selected cells were expanded and the second flow sorting was performed to purify and enrich the EGFP positive cells.

\section{Somatic cell nuclear transfer}

Animal use in this study was approved by the Institutional Animal Care and Use Committee (IACUC). SCNT was performed using in vitro matured oocytes (DeSoto Biosciences Inc. St Seymour, TN. and Minitub of America, Mount Horeb, WI.). Cumulus cells were removed from the oocytes by pippeting in $0.1 \%$ hyaluronidase. Only oocytes with normal morphology and a visible polar body were selected for cloning. Oocytes were incubated in manipulation media (Ca-free NCSU-23 with $5 \%$ FBS) containing $5 \mathrm{mg} / \mathrm{mL}$ bisbenzimide and $7.5 \mathrm{mg} / \mathrm{mL}$ cytochalasin B for $15 \mathrm{~min}$. Following this incubation period, oocytes were enucleated by removing the first polar body and metaphase II plate, and one single cell was injected into each enucleated oocyte. Electrical fusion was induced with a BTX cell electroporator (Harvard Apparatus, Hol-liston, MA). Couples were exposed to two DC pulses of $140 \mathrm{~V}$ for $50 \mathrm{~ms}$ in $280 \mathrm{mM}$ Mannitol, $0.001 \mathrm{mM} \mathrm{CaCl}_{2}$, and $0.05 \mathrm{mM} \mathrm{MgCl}_{2}$. One hour later, reconstructed oocytes were activated by two DC pulses of $120 \mathrm{~V}$ for $60 \mathrm{~ms}$ in $280 \mathrm{mM}$ Mannitol, $0.1 \mathrm{mM}$ $\mathrm{CaCl}_{2}$ and $0.05 \mathrm{mM} \mathrm{MgCl}_{2}$ [14]. After activation, oocytes were placed back in NCSU-23 medium with $0.4 \%$ bovine serum albumin BSA and cultured at $38.5^{\circ} \mathrm{C}, 5 \% \mathrm{CO}_{2}$ in a humidified atmosphere, for less than $1 \mathrm{~h}$ before being transferred into the recipient. Recipients were synchronized occidental pigs on their first day of estrus.

\section{Genotyping of EGFP transgenic fetuses}

The pregnancy was terminated at 30 day and fetuses were harvested. Genomic DNA was extracted using DNeasy Blood \& Tissue Kit (Qiagen). The EGFP sequence in pEGFP-N1 was used to design the forward primer (5'- CTGGTCGAGCTGGACGGCGACG-3') and reverse primer (5'-CACGAACTCCAGCAGGACCATG-3') to amplify 630 bp PCR product. The $20 \mu \mathrm{l}$ of reaction mixture contained $10 \mu \mathrm{l}$ of 2 x Go-Taq Green Master Mix (Promega, Madison, WI), 5 pmol of each primer, and $50 \mathrm{ng}$ of genomic DNA. The initial denaturation was performed at $94^{\circ} \mathrm{C}$ for $2 \mathrm{~min}$, followed by 30 cycles of $94^{\circ} \mathrm{C}$ for $30 \mathrm{sec}, 60^{\circ} \mathrm{C}$ for $30 \mathrm{sec}$ and $72^{\circ} \mathrm{C}$ for $45 \mathrm{sec}$, 
Li et al. Transplantation Technology 2014,

and a final extension step of $72^{\circ} \mathrm{C}$ for 5 min. Genomic DNA extracted from domestic cells and EGFP positive LDC were used as negative and positive control, respectively.

\section{Confocal microscope analysis of EGFP expression in LDC and fetal tissues}

The presence of EGFP expression driven by the ROSA26 promoter was examined in LDC, fetal tissue and fetal fibroblasts isolated from genetically modified pigs using confocal microscopy. Cells or frozen sections were fixed in $4 \%$ paraformaldehyde in phosphate buffered saline (PBS) and blocked with $50 \%$ Odyssey buffer (LI-COR Biosciences, Lincoln, NE) in PBS. Liver derived cells were labeled with anti-porcine CD31 antibody detected with donkey anti-goat secondary antibody conjugated to Dylight 549 in PBS. Cell nuclei were stained with DAPI (Invitrogen) and mounted with Prolong Gold (Invitrogen). Fetal tissue and fibroblasts were labeled with anti-EGFP antibody conjugated to alexa fluor 647 and stained with DAPI. Images were collected with an Olympus FV1000 confocal microscope.

\section{Results}

\section{Cloning of pig ROSA26 promoter}

The porcine ROSA26 promoter region was identified by blast searching the NCBI pig genome database using the human and mouse ROSA26 promoter sequences, respectively. A sequence with $86 \%$ identity to human ROSA26 promoter and $79 \%$ identity to mouse ROSA26 promoter was located on porcine chromosome 13. A DNA fragment containing the potential porcine ROSA26 promoter region was amplified by $\mathrm{PCR}$, cloned, and sequenced, and compared to mouse and human (Figure 1). The cloned DNA fragment shared 99\% identities to the sequence on sus scrofa chromosome 13 (NCBI).

\section{Porcine ROSA26 promoter activity in vitro}

EGFP expression driven by the porcine ROSA26 promoter in LDC was detected by confocal microscopy after transient transfection (Figure 2). To further assess the promoter strength we used flow cytometry to compare the porcine ROSA26, murine $\mathrm{MHC}$ class I $\mathrm{H}-2 \mathrm{~K}^{\mathrm{b}}$ and $\mathrm{CMV}$ promoters. The $\mathrm{H}-2 \mathrm{~K}^{\mathrm{b}}$ promoter, suggested to be moderate and ubiquitous, was used to drive human a 1,2-FT, CD55, CD59 and TRAIL on endothelial cells in transgenic pigs $[3,15]$. The CMV promoter is commonly known to be a strong promoter in vitro. Flow cytometry analysis showed that some LDC transfected with $\mathrm{pH}-2 \mathrm{~K}^{\mathrm{b}}$-EGFP were only slightly brighter than the LDC transfected with pROSA26-EGFP, suggesting that the strength of the murine $\mathrm{H}-2 \mathrm{~K}^{\mathrm{b}}$ promoter is similar to the porcine ROSA26 promoter. The CMV promoter was much stronger than murine $\mathrm{H}-2 \mathrm{~K}^{\mathrm{b}}$ and porcine ROSA26 promoters in vitro (Figures $\mathbf{3} \mathbf{a}$ and $\mathbf{3 b}$ ).

\section{Somatic cell nuclear transfer}

Liver derived cells positive for EGFP enriched by G418 selection and flow sorting were used as nuclear donors for SCNT. Two hundred thirty-three cloned embryos were transferred to two gilts. One became pregnant. A total of four fetuses were collected at day 30 . One fetus was normal and three fetuses were resorbed.

\section{Porcine ROSA26 promoter activity in vivo}

All four fetuses showed EGFP transgene integration (Figure 4a). Variable expression of EGFP in fetal tissues was observed by confocal microscope analysis. Moderate EGFP expression was found in fetal liver and weak EGFP expression was observed in fetal heart as compared to control fetal liver tissue. Control fetal heart tissue was unavailable. EGFP expression was also observed in isolated fetal fibroblasts and tissues (Figure $4 \mathbf{b}$ ). These results suggest that porcine ROSA26 is a ubiquitous promoter in vivo.

\section{Discussion}

In this study, we successfully cloned, sequenced and evaluated the porcine ROSA26 promoter to control the expression of a reporter gene. EGFP driven by the porcine ROSA26 promoter was expressed in LDC in vitro and liver, heart and fibroblasts from 30-day old fetus.

Several promoters from different origins have been previously used to drive transgene expression in pigs with variable results. The CMV promoter has been widely used for transgene expression but is prone to silencing by methylation [16] and unpredictable transgene expression ranging from low to strong in different tissues [17]. The Chicken b-actin promoter coupled with enhancer elements from the CMV promoter and rabbit b-globin drives EGFP expression in transgenic pigs in a stable and uniform manner [18]. However, the same promoter was unpredictable when driving the human A20 gene [19]. A study demonstrated that human intercellular adhesion molecule 2 (ICAM-2) promoter was much weaker in pig than in mice, suggesting that there may be a need for additional regulatory elements to achieve species-specific gene expression in pig [20]. Mouse major histocompatibility complex class I gene $\mathrm{H}-2 \mathrm{~K}^{\mathrm{b}}$ promoter was used to express human TRAIL (tumor necrosis factor-alpharelated apoptosis-inducing ligand) in transgenic pigs. TRAIL expression was detected in all the tissues yet with variable expression levels [15]. Expression strength of the ROSA26 promoter was comparable to the $\mathrm{H}-2 \mathrm{~K}^{\mathrm{b}}$ promoter and similar to previous reports in the human and mouse, demonstrating moderate activity in vitro and in range of tissues in vivo.

Development of a1,3-galactosyltransferase knockout (GGTA1-KO) pigs overcame a major hurdle in xenotransplantation by reducing antibody mediated rejection. Recently, we have successfully generated GGTA1/CMAH double knockout pig using ZFN technology [21]. This double knockout pig deficient in N-glycolylneuraminic acid (Neu5Gc) and a-Gal exhibits much less human antibody binding compared to GGTA1-KO pig. Generation of transgenic pigs expressing human complement regulatory proteins, human anti-apoptosis, 
Li et al. Transplantation Technology 2014,

\begin{tabular}{|c|c|c|c|c|c|c|c|}
\hline & 10 & 20 & 30 & 40 & 50 & 60 & 70 \\
\hline Human & & & & & a & & G \\
\hline
\end{tabular}
GGT GAA BA CA T T GCA CAAGTAA CA TGA GAAA GCA GAAAA T GCAGGTCA TA CA CGCACCCCTGACCCA GACCA GCA

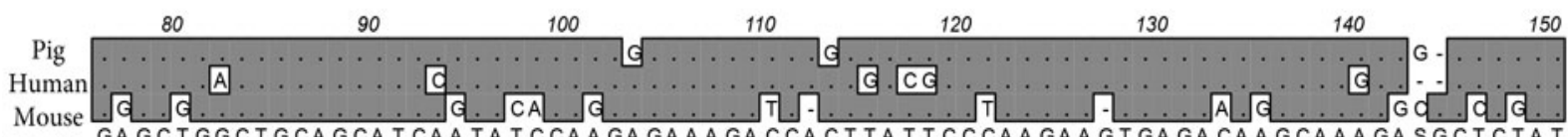
GA GC T GGCT GCA GCA T CAA TA T C CAA GA GAAA GA CCA CT TA T T CCCAA GAA G TGA GA CAA GCAAA GA S GCTCTAT
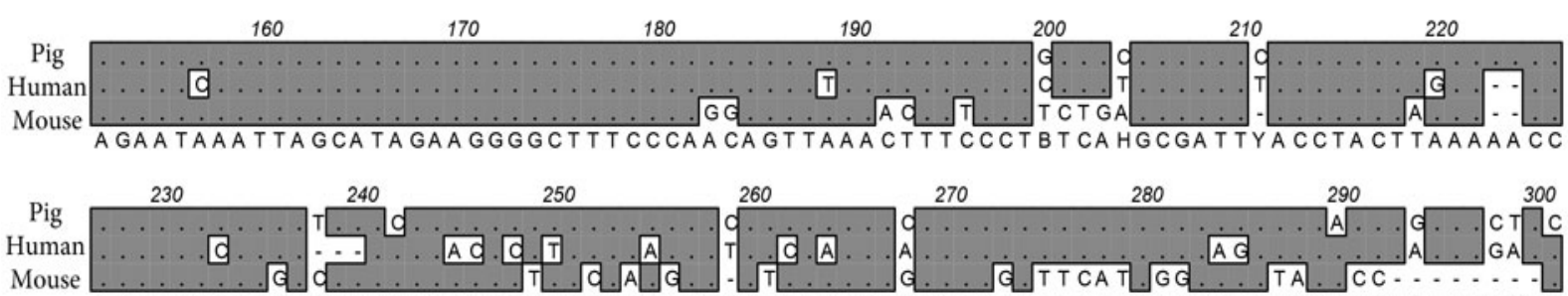
A GGGCTTTTTCYCACTACCA TTCACTTCGCATYCCTGGCTTVCA CGCA GA GGGAAA GGCAATTCA TARA GGSWAT

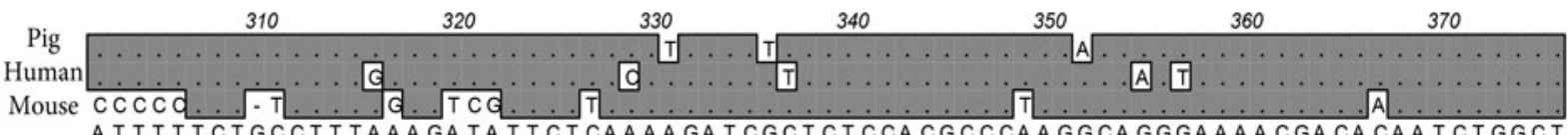
A TT TTCTGCCTTTAAA GA TA T TCTCAAAAGA TCGCTCTCCA CGCCCAAGGCA GGGAAAA CGACACAA TCT GGCT

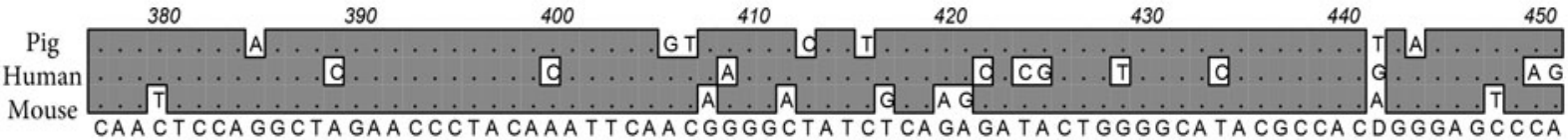

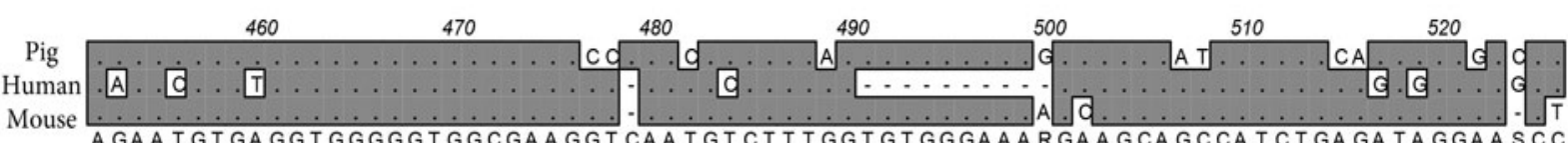

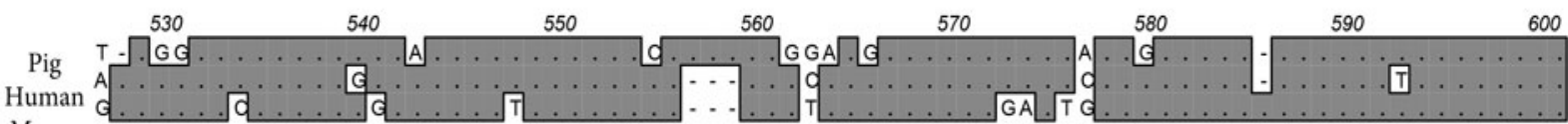

Mouse DGAAAACGAGAGGAAAGGCGTCCAGGAAGATTCTTA BGGAGGGGAGATCGVGGCCCCCACGAGCGACCAGAGTTG

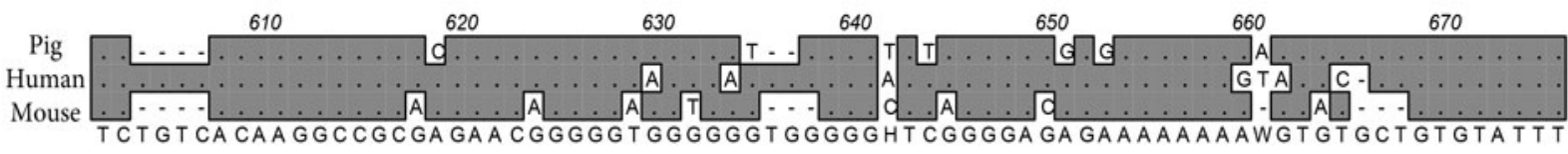

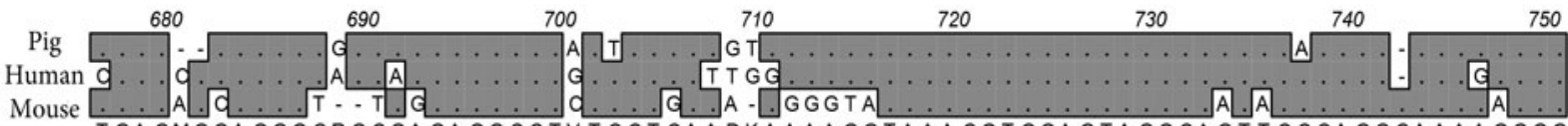
TGA GM GA GGGCR G CGA GA GGCC TV TCCT CAA DKAA AA GG TAAA CG T GGA GTA GGCA G T TCCA GGCAAAAGGGG

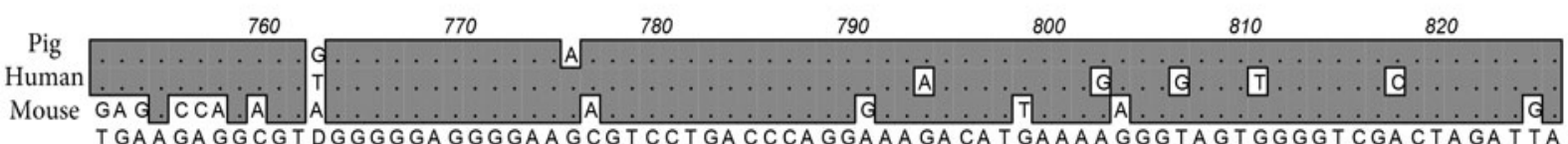
TGAAGA GGCGT DGGGGGAGGGGAAGCGTCCTGACCCAGGAAAGACA TGAAAAGGGAGTGGGGTCGACTAGA TA Pig
Mumane

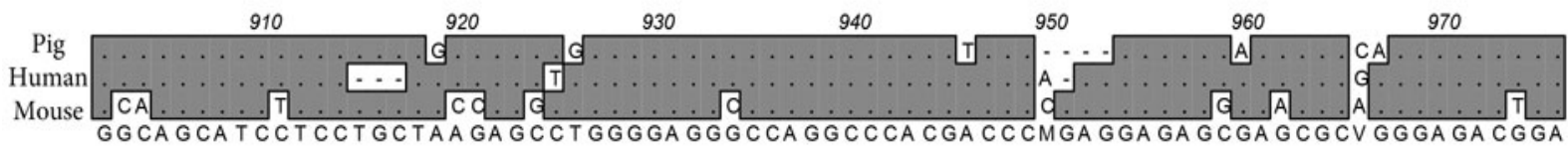


Li et al. Transplantation Technology 2014,

http://www.hoajonline.com/journals/pdf/2053-6623-2-1.pdf

doi: 10.7243/2053-6623-2-1

continuation of Figure 1.

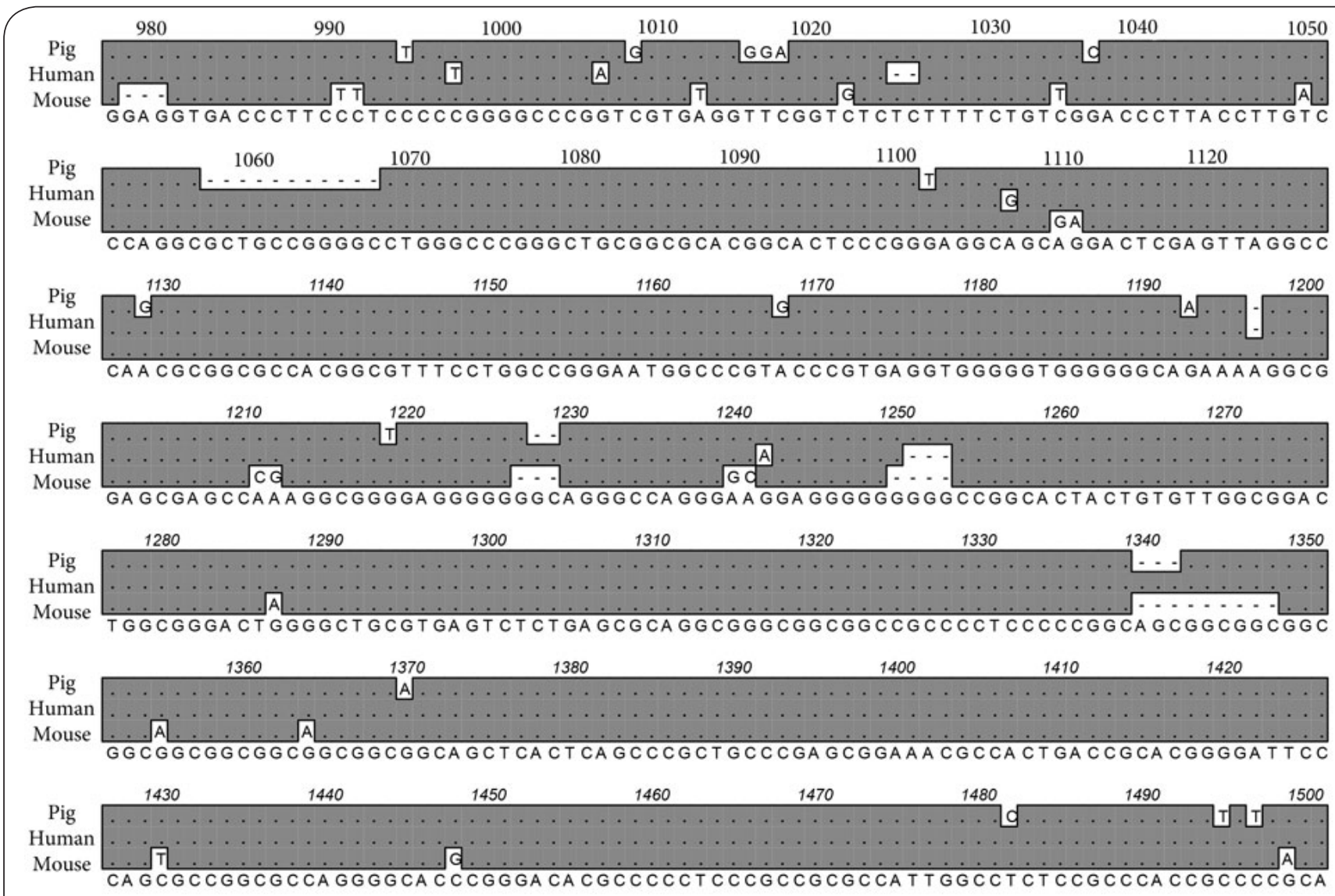
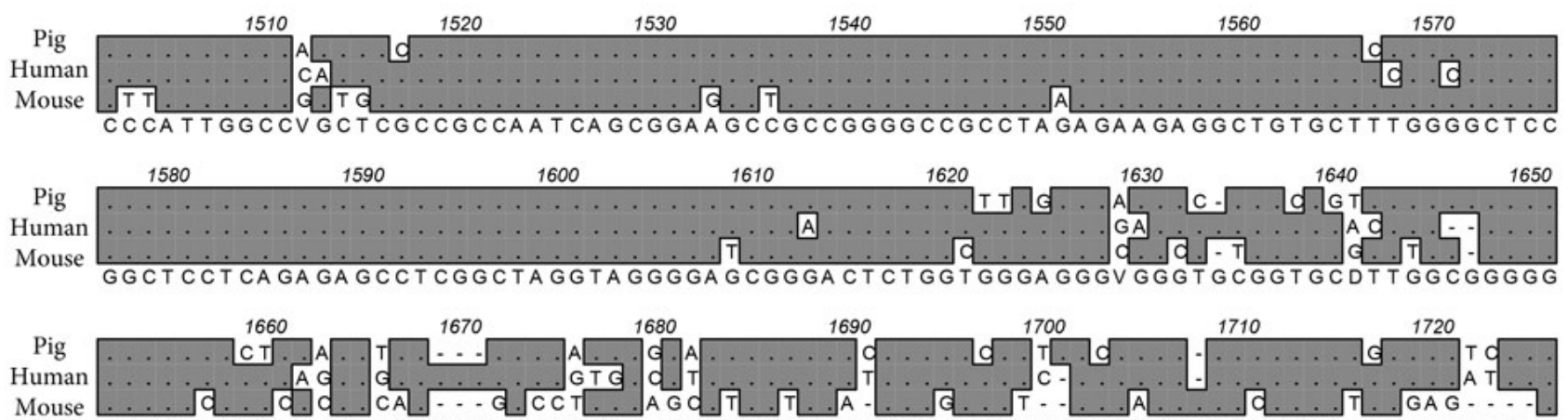

Mouse .
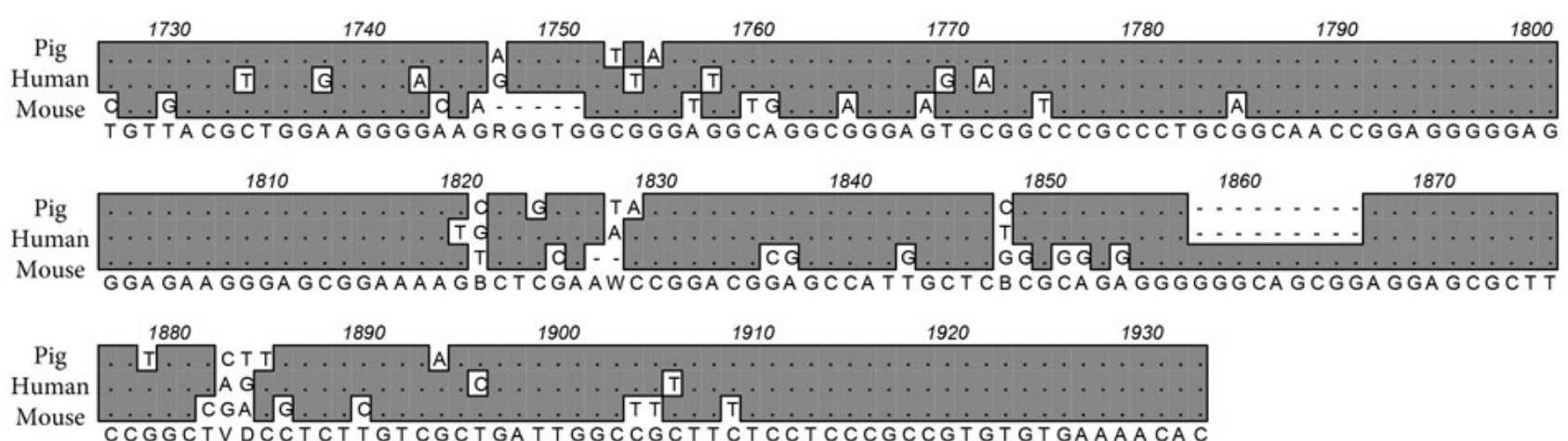

Figure 1. Alignment of cloned porcine ROSA26 promoter with human and mouse ROSA26 promoters. 


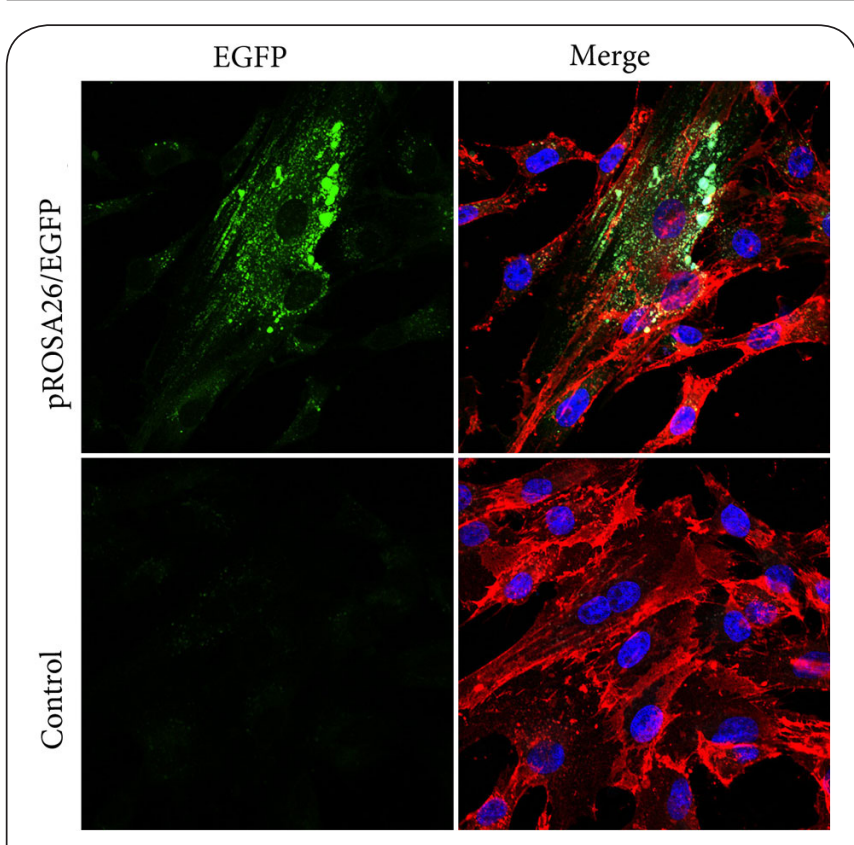

Figure 2. Transient expression of EGFP (green) in CD31 positive LDC (red) driven by the porcine ROSA26 promoter. Nuclei (blue) are shown in the merge column indicating intact cells.
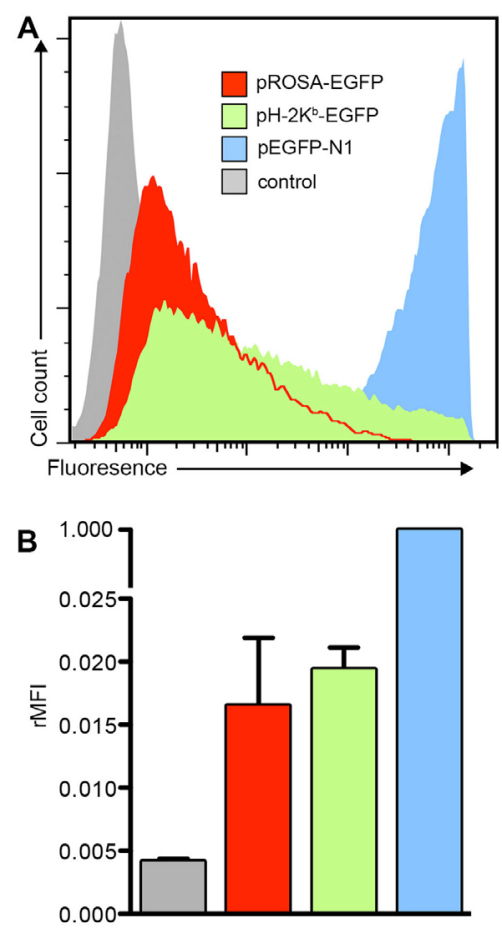

Figure 3. Comparison of porcine ROSA26 promoter activity with $\mathrm{H}-2 \mathrm{~K}^{\mathrm{b}}$ and $\mathrm{CMV}$ promoters. A. Representative histogram, B. Relative mean fluorescent intensity (rMFI) and standard deviation, $n=3$. Note the change in scale to accommodate the low promoter strength of ROSA26 and H-2 $\mathrm{K}^{\mathrm{b}}$.

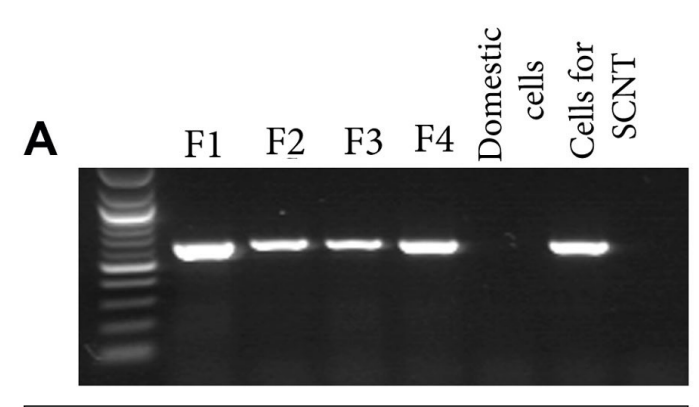

B pROSA26/EGFP WT

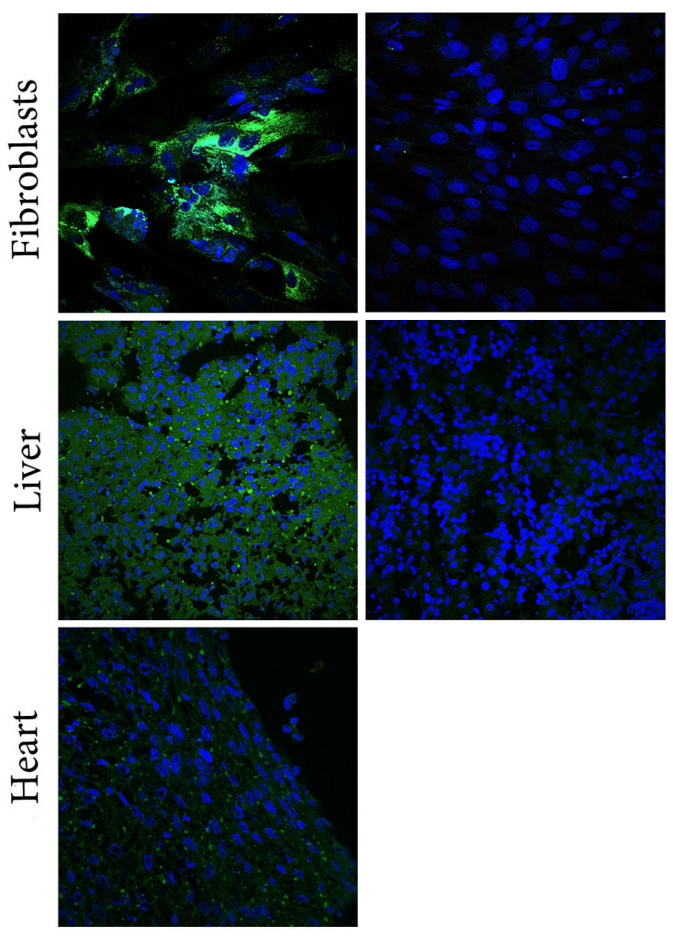

Figure 4. A. PCR analysis of EGFP gene integration in transgenic fetuses. B. Confocal microscope analysis of EGFP expression in transgenic fetal fibroblasts, heart and liver.

anti-inflammatory and anti-coagulation genes on GGTA1/ CMAH double KO background may be crucial to the success of xenotransplantation.

Reliable and consistent expression of transgenes depends on the selection of suitable promoters as well as the transgene integration site. Endogenous porcine ROSA26 and the other ubiquitous exogenous promoters such as PGK, EF1a, UBC, CAG could be used to achieve a desired expression level of transgene at the ROSA26 locus. Integration of exogenous promoters at ROSA26 in both sense and antisense orientation had a large effect on transgene expression [22]. Targeting transgenes to the ROSA26 locus by homologous recombination is inefficient and time consuming in porcine somatic cells used for SCNT to generate transgenic pigs. Currently, several methods have been developed to accelerate the process of 
Li et al. Transplantation Technology 2014,

genomic modification by generation of a DNA double-strand break (DSB) at a specified locus in various species, such as zinc finger nucleases (ZFN), transcription activator-like effector nucleases (Talens) and clustered regularly interspaced short palindromic repeat (CRISPR)/Cas system [23-25]. Combined with these genetic engineering tools, transgenes could be efficiently delivered to the porcine ROSA26 locus where they can be driven by the endogenous ROSA26 promoter.

In conclusion, our study demonstrated that the porcine ROSA26 promoter is ubiquitous and can be utilized in pig transgenesis. Targeting transgenes to ROSA26 locus along with further genetic modification of the pig genome may provide suitable organs for xenotransplantation.

\section{Competing interests}

The authors declare that they have no competing interests.

Authors' contributions

\begin{tabular}{|l|c|c|c|c|c|}
\hline Authors' contributions & PL & CB & JE & PJC & AJT \\
\hline Research concept and design & $\checkmark$ & $\checkmark$ & -- & -- & $\checkmark$ \\
\hline Collection and/or assembly of data & $\checkmark$ & $\checkmark$ & $\checkmark$ & -- & -- \\
\hline Data analysis and interpretation & $\checkmark$ & $\checkmark$ & $\checkmark$ & -- & -- \\
\hline Writing the article & $\checkmark$ & $\checkmark$ & -- & -- & -- \\
\hline Critical revision of the article & $\checkmark$ & $\checkmark$ & $\checkmark$ & $\checkmark$ & $\checkmark$ \\
\hline Final approval of article & -- & -- & -- & -- & $\checkmark$ \\
\hline Statistical analysis & $\checkmark$ & $\checkmark$ & -- & -- & -- \\
\hline
\end{tabular}

\section{Acknowledgement}

This study was supported by IU Health Transplant Institute. The authors thank Fuqin Yin, Amanda Kleiman and Bess Ivary for technical assistance, MRI (Methodist Research Institute) and LARC (Laboratory animal research center) staff for taking care of the animals. This investigation utilized a facility constructed with support from Research Facilities Improvement Program grant number C06RR10601-01 from the National Center for Research Resources, National Institute of Health.

Publication history

EIC: Stephen C Strom, Karolinska Institute, Sweden.

Received: 31-Aug-2013 Revised: 16-Nov-2013

Accepted: 17-Dec-2013 Published: 03-Dec-2013

\section{References}

1. Ekser B, Long C, Echeverri GJ, Hara H, Ezzelarab M, Lin CC, de Vera ME, Wagner R, Klein E, Wolf RF, Ayares D, Cooper DK and Gridelli B. Impact of thrombocytopenia on survival of baboons with genetically modified pig liver transplants: clinical relevance. Am J Transplant. 2010; 10:273-85. | Article I PubMed

2. Ekser B, Ezzelarab M, Hara H, van der Windt DJ, Wijkstrom M, Bottino R, Trucco $\mathrm{M}$ and Cooper DK. Clinical xenotransplantation: the next medical revolution? Lancet. 2012; 379:672-83. | Article | PubMed

3. Cowan PJ, Aminian A, Barlow H, Brown AA and Chen CG. Renal xenografts from triple-transgenic pigs are not hyperacutely rejected but cause coagulopathy in non-immunosuppressed baboons. Transplantation. 2000; 69:2504-15. | Article | PubMed

4. Wheeler DG, Joseph ME, Mahamud SD, Aurand WL, Mohler PJ, Pompili VJ, Dwyer KM, Nottle MB, Harrison SJ, d'Apice AJ, Robson SC, Cowan PJ and Gumina RJ. Transgenic swine: expression of human CD39 protects against myocardial injury. J Mol Cell Cardiol. 2012; 52:958-61. | Article |

\section{PubMed Abstract | PubMed Full Text}

5. Aigner $\mathrm{B}, \mathrm{Klymiuk} \mathrm{N}$ and Wolf $\mathrm{E}$. Transgenic pigs for xenotransplantation: selection of promoter sequences for reliable transgene expression. Curr Opin Organ Transplant. 2010; 15:201-6. | Article I PubMed

6. Friedrich $\mathrm{G}$ and Soriano P. Promoter traps in embryonic stem cells: a genetic screen to identify and mutate developmental genes in mice. Genes Dev. 1991; 5:1513-23. | Article | PubMed

7. Zambrowicz BP, Imamoto A, Fiering S, Herzenberg LA, Kerr WG and Soriano P. Disruption of overlapping transcripts in the ROSA beta geo 26 gene trap strain leads to widespread expression of beta-galactosidase in mouse embryos and hematopoietic cells. Proc Natl Acad Sci U S A. 1997; 94:3789-94. | Article | PubMed Abstract | PubMed Full Text

8. Irion S, Luche H, Gadue P, Fehling HJ, Kennedy M and Keller G. Identification and targeting of the ROSA26 locus in human embryonic stem cells. Nat Biotechnol. 2007; 25:1477-82. I Article I PubMed

9. Kobayashi T, Kato-Itoh M, Yamaguchi T, Tamura C, Sanbo M, Hirabayashi $\mathrm{M}$ and Nakauchi $\mathrm{H}$. Identification of rat ROSA26 locus enables generation of knock-in rat lines ubiquitously expressing tdTomato. Stem Cells Dev. 2012; 21:2981-6. | Article | PubMed Abstract | PubMed Full $\underline{\text { Text }}$

10. Yu J and McMahon AP. Reproducible and inducible knockdown of gene expression in mice. Genesis. 2006; 44:252-61. | Article | PubMed

11. Dow LE, Premsrirut PK, Zuber J, Fellmann C, McJunkin K, Miething C, Park Y, Dickins RA, Hannon GJ and Lowe SW. A pipeline for the generation of shRNA transgenic mice. Nat Protoc. 2012; 7:374-93. | Article | PubMed Abstract | PubMed Full Text

12. Li P, Estrada J, Zhang F, Waghmare SK and Mir B. Isolation, characterization, and nuclear reprogramming of cell lines derived from porcine adult liver and fat. Cell Reprogram. 2010; 12:599-607. I Article I PubMed

13. Ducrest AL, Amacker M, Lingner J and Nabholz M. Detection of promoter activity by flow cytometric analysis of GFP reporter expression. Nucleic Acids Res. 2002; 30:e65. | Article | PubMed Abstract | PubMed Full Text

14. Estrada J, Sommer J, Collins B, Mir B, Martin A, York A, Petters RM and Piedrahita JA. Swine generated by somatic cell nuclear transfer have increased incidence of intrauterine growth restriction (IUGR). Cloning Stem Cells. 2007; 9:229-36. | Article | PubMed

15. Klose R, Kemter E, Bedke T, Bittmann I, Kelsser B, Endres R, Pfeffer K, Schwinzer $R$ and Wolf E. Expression of biologically active human TRAIL in transgenic pigs. Transplantation. 2005; 80:222-30. | Article I PubMed

16. Kong Q, Wu M, Huan Y, Zhang L, Liu H, Bou G, Luo Y, Mu Y and Liu Z. Transgene expression is associated with copy number and cytomegalovirus promoter methylation in transgenic pigs. PLOS One. 2009; 4:e6679. | Article | PubMed Abstract | PubMed Full Text

17. Petersen B, Ramackers W, Tiede A, Lucas-Hahn A, Herrmann D, Barg-Kues $B$, Schuettler W, Friedrich L, Schwinzer R, Winkler M and Niemann H. Pigs transgenic for human thrombomodulin have elevated production of activated protein C. Xenotransplantation. 2009; 16:486-95. | Article | PubMed

18. Brunetti D, Perota A, Lagutina I, Colleoni S, Duchi R, Calabrese F, Seveso M, Cozzi E, Lazzari G, Lucchini F and Galli C. Transgene expression of green fluorescent protein and germ line transmission in cloned pigs derived from in vitro transfected adult fibroblasts. Cloning Stem Cells. 2008; 10:409-19. | Article | PubMed

19. Oropeza M, Petersen B, Carnwath JW, Lucas-Hahn A, Lemme E, Hassel P, Herrmann D, Barg-Kues B, Holler S, Queisser AL, Schwinzer R, Hinkel R, Kupatt $\mathrm{C}$ and Niemann $\mathrm{H}$. Transgenic expression of the human $\mathrm{A} 20$ gene in cloned pigs provides protection against apoptotic and inflammatory stimuli. Xenotransplantation. 2009; 16:522-34. I Article I PubMed

20. Cowan PJ, Shinkel TA, Fisicaro N, Godwin JW, Bernabeu C, Almendro N, Rius C, Lonie AJ, Nottle MB, Wigley PL, Paizis K, Pearse MJ and d'Apice AJ. Targeting gene expression to endothelium in transgenic animals: $a$ comparison of the human ICAM-2, PECAM-1 and endoglin promoters. Xenotransplantation. 2003; 10:223-31. | Article | PubMed

21. Lutz AJ, Li P, Estrada JL, Sidner RA, Chihara RK, Downey SM, Burlak C, Wang ZY, Reyes LM, Ivary B, Yin F, Blankenship RL, Paris LL and Tector 
Li et al. Transplantation Technology 2014,

http://www.hoajonline.com/journals/pdf/2053-6623-2-1.pdf

AJ. Double knockout pigs deficient in $\mathrm{N}$-glycolylneuraminic acid and galactose alpha-1,3-galactose reduce the humoral barrier to xenotransplantation. Xenotransplantation. 2013; 20:27-35. | Article | PubMed

22. Chen CM, Krohn J, Bhattacharya S and Davies B (2011) A comparison of exogenous promoter activity at the ROSA26 locus using a PhiC31 integrase mediated cassette exchange approach in mouse ES cells. PLOS One 6: e23376. | Article

23. Li P, Estrada JL, Burlak C and Tector AJ. Biallelic knockout of the alpha-1,3 galactosyltransferase gene in porcine liver-derived cells using zinc finger nucleases. J Surg Res. 2013; 181:e39-45. | Article | PubMed

24. Bogdanove AJ and Voytas DF. TAL effectors: customizable proteins for DNA targeting. Science. 2011; 333:1843-6. | Article | PubMed

25. Cong L, Ran FA, Cox D, Lin S, Barretto R, Habib N, Hsu PD, Wu X, Jiang W, Marraffini LA and Zhang F. Multiplex genome engineering using CRISPR/ Cas systems. Science. 2013; 339:819-23. | Article | PubMed Abstract | PubMed Full Text

\section{Citation:}

Li P, Burlak C, Estrada J, Cowan PJ and Tector AJ. Identification and cloning of the porcine ROSA26 promoter and its role in transgenesis. Transplant Technol. 2014; 2:1.

http://dx.doi.org/10.7243/2053-6623-2-1 